\title{
Recurrent juvenile parotitis: a rare bilateral presentation
}

\author{
Mudit Gupta, ${ }^{1}$ Kumbar Jayadevappa Sundaresh, ${ }^{2}$ Srinivas Kandula, $^{3}$ \\ Vandana J Rathva ${ }^{4}$
}

${ }^{1}$ Department of Oral Medicine \& Radiology, Uttaranchal Dental and Medical Research Institute, Dehradun, Uttarakhand, India

${ }^{2}$ Department of Conservative Dentistry and Endodontics, K.M Shah Dental College \& Hospital, Sumandeep Vidyapeeth, Vadodara, Karnataka, India

${ }^{3}$ Department of Oral Medicine \& Radiology, AECS Maaruti Dental College, Bangalore,

Karnataka, India

${ }^{4}$ Department of Periodontics, K.M. Shah Dental College and Hospital, Baroda, Gujarat, India

Correspondence to Dr Vandana J Rathva, drvandana07@hotmail.com

Accepted 7 November 2013

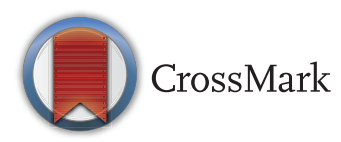

To cite: Gupta $\mathrm{M}$ Sundaresh KJ, Kandula S, et al. BMJ Case Rep

Published online: [please include Day Month Year] doi:10.1136/bcr-2013201715

\section{DESCRIPTION}

A 15 -year-old boy presented with a 1.5 -year history of recurrent swelling on the right and left hand sides of his face. His medical history revealed 3-4 bouts of similar episodes on each side of his face. At the time of the patient's visit to us, no swelling was observed. On intraoral examination, there was no evidence of any swelling or lesion. A provisional diagnosis of juvenile recurrent parotitis (JRP) of the right and left parotid salivary glands was made based on the history of recurrent facial swelling with moderate to severe pain in the region of the parotid glands associated with fever and malaise and the asymptomatic period between attacks. A sialographic investigation of both parotid glands showed the normal course and calibre of Stenson's duct, no evidence of stricture, dochitis, calcification or obstruction. However, we noted an accumulation of blobs of contrast media corresponding to sialectasis in the left (figure 1) and right (figure 2) parotid glands. Dilation of the peripheral duct was also observed in the right parotid gland. Thus, a final diagnosis of JRP of the right and left parotid glands was confirmed.

JRP is one of the non-obstructive, non-neoplastic disorders characterised by recurrent episodes of inflammation, manifesting as swelling and pain in the parotid gland. It commonly occurs in children aged 3-6 years. ${ }^{1}$ Leerdam et $a l^{2}$ have given a

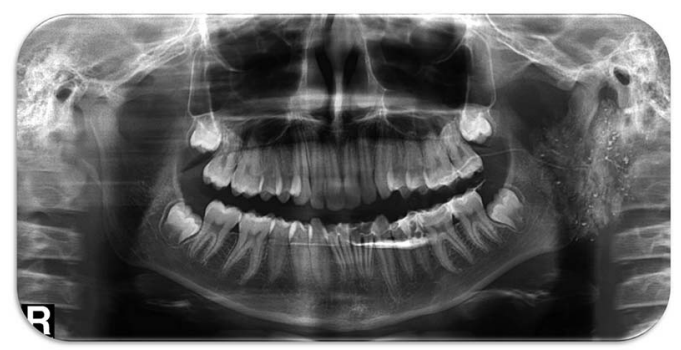

Figure 1 Panoramic radiograph showing a sialogram of the left parotid gland with accumulation of blobs of contrast media.

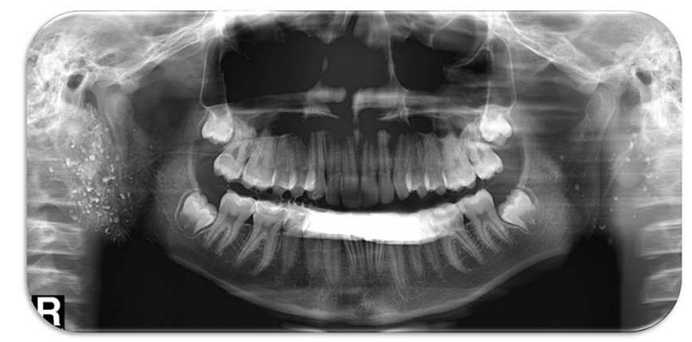

Figure 2 Panoramic radiograph showing a sialogram of the right parotid gland with accumulation of blobs of contrast media.

bimodal age of distribution, i.e. one at 2-5 years and the other at 10 years. In our case, the first episode occurred around 13-14 years of age, which is an unusual finding.

\section{Learning points}

- Juvenile recurrent parotitis is one of the common causes of salivary gland enlargement during childhood.

- Conventional sialography procedure is still a very useful investigative procedure which gives glandular details.

- Medicinal treatment is not required for every disease process, and in many cases a wait and watch policy should be adopted.

Competing interests None.

Patient consent Obtained.

Provenance and peer review Not commissioned; externally peer reviewed.

\section{REFERENCES}

1 Getarud A, Lindvall AM, Nylen O. Follow up study of recurrent parotitis in children. Ann Otol Rhinol Laryngol 1988;97:341-6.

2 Leerdam CM, Martin HC, Isaacs D. Recurrent parotitis of childhood. J Paediatr Child Health 2005;41:631-4. 
Copyright 2014 BMJ Publishing Group. All rights reserved. For permission to reuse any of this content visit http://group.bmj.com/group/rights-licensing/permissions.

BMJ Case Report Fellows may re-use this article for personal use and teaching without any further permission.

Become a Fellow of BMJ Case Reports today and you can:

- Submit as many cases as you like

- Enjoy fast sympathetic peer review and rapid publication of accepted articles

- Access all the published articles

- Re-use any of the published material for personal use and teaching without further permission

For information on Institutional Fellowships contact consortiasales@bmjgroup.com

Visit casereports.bmj.com for more articles like this and to become a Fellow 